\title{
Sustainable Agroforestry Models for Proposed Food Production in Post-Mined Land Sites of South Sumatera
}

\author{
Bandi Hermawan ${ }^{\#}$ \\ \# Department of Agricultural Cultivation, University of Bengkulu, Bengkulu, 38178, Indonesia \\ E-mail: bhermawan@unib.ac.id
}

\begin{abstract}
The reclamation areas of the opencast coal mining in South Sumatera are predominantly compact and nutrient-poor, marginal sites but have a high potential for cultivation of fast-growing trees and agricultural crops. This paper aims to promote several models of agroforestry in the post-mined land in South Sumatera as a new strategy in reclaiming degraded soil properties for both enviroment and economic purposes. About 5,000 ha of coal mining areas were observed to characterize the landscape and soil properties in the area, then overlaid with the landuse maps of post-mining plans issued by the company. Results showed that about 1,730 ha of the reclamation areas was suitable for agroforestry while the rest was for utilities, camping ground, water pond and grassland. Three models were proposed for the agroforestry areas, including (i) agrisilviculture model (1,190 ha), (ii) silvihorticulture model (203 ha), and (iii) local-species collection model for agrihortisilviculture (337 ha). Prior to the agroforestry establishment, all reclamation sites were subjected to the revegetation with fast-growing trees and other rejuvenation treatments in order to restore favour soil and microclimate conditions. The proposed components for each model were as follows: for agrisilviculture model were cultivation on the alley cropping system of trees and food crops, for silvihorticulture model were the plantation of fruit trees in the bench of water pond, and for local-species collection model for agrihortisilviculture were the cultivation of local forest and food crop species.
\end{abstract}

Keywords - Agroforestry; proposed food production; post-mined land; reclamation vegetation; soil properties.

\section{INTRODUCTION}

The process of the opencast coal mining in the Bukit Asam region of South Sumatera, Indonesia, begins with the clearance of original vegetation and the removal of topsoil layers to the final undisturbed areas or to the temporarily stock piles before moved to the final dumping areas [1]. The overburden materials covering the lignite seam are removed using Two Bucket Wheel Excavators (BWE) to a belt conveyor, and transported to the final mine's dumpsites. The materials are spreaded out using spreaders to shape the relief of the future post-mining landscape, then covered with pre-deposited topsoils. Lignite materials are excavated from the opening sites using BWE and transported to stock piles using a belt conveyor and trucks, leaving a large lake-like open area. The final step of the process is to reclaim the fuctions of post-mine areas including dumping and waterfilled open sites.

The reclamation land at dumping areas of the opencast coal mine in South Sumatera is predominantly compact and nutrient-poor, marginal sites. Under the eight-years period of revegetation process, soil bulk density and penetration resistance at the upper layer are about $1,32 \mathrm{~g} \mathrm{~cm}^{-3}$ and 2,75 $\mathrm{MPa}$, respectively, indicating high soil compaction, while soil organic content is less than 2,0 \% showing poor nutrient supply to the plant [2]. However, the reclaimed dumping sites cover areas of about 1,730 ha and have a high potential for cultivation of fast-growing woody species and agricultural crops. Further study on four additonal years of revegetation at the same areas indicates that the average soil bulk density and penetration resistance decrease to be more favourable conditions of $1,20 \mathrm{~g} \mathrm{~cm}^{-3}$ and $2.62 \mathrm{MPa}$, respectively [3]. Soil organic matter content also increases significantly followed by increases in soil nitrogen and phosporous contents by 0,08 and $1,75 \%$, respectively.

Agroforestry is defined by International Council for Research in Agroforestry as "a system of land use where woody perenials are deliberately used on the same land management units as annual agricultural crops and/or animals, either sequentially or simultaneously, with the aim of obtanining greater outputs on sustained basis" [4]. The main components of agroforestry system include woody perennials, annual crops and livestock, either managed in a temporal or spatial sequence on the basis of sustainability. On temporal basis, trees and woody species are rotated for 5 to 40 years with the cultivation of annual crops for 1 to 3 years. On the other hand, growing food crops in alleys formed by contour rows of trees and woody species is an 
example of the groforestry system on the basis of spatial sequence, which is also called alley cropping.

The practice of agroforestry has many advantages, some of which are improvement in soil properties (structure, organic carbon and nutrient status), production of fruit, timber and fuelwood, transport of deep seated nutrient on the soil surface, and environmental conservation by fixing carbon dioxide $\left(\mathrm{CO}_{2}\right)$ and releasing oxygen $\left(\mathrm{O}_{2}\right)$. When perennial crops are involved in mature agroforestry systems, physiological and morphological differences between trees and perennial crops, such as stratified rooting zones, may reduce belowground competition as reported by several researchers. Applying fertilizer to the shade trees during nursery phase of perennial crop can mitigate early growth competition in the field when the crop is transplanted in the trees-cocoa agroforestry system [5]. Timber species may be promoted for the shade component of cacao plantations at the agroforestry system, due to their potential production and the fact that their presence does not negatively affect cocoa yields [6].

The Government of Muara Enim Regency, South Sumatera Province, Indonesia and PT. Bukit Asam Coal Company have launched a long-lasting agreement in 2004 to promote the green productive land in the post-mined area. The agreement is stated in a Regional Regulation of Muara Enim Regency involving the establishment of Great Forest Park in the post-mined land when the mine activities come to end by 2040 or later [7]. The brief guideline for the use of post-mined land cited in the local regulation is as follows: (i) dumping and mining-free areas will be used for agroforestry systems, (ii) post-mined pits will be left open and filled with water for recreation and fishery purposes, and (iii) the infrastructure will be used for community development including schools and recreation centers. The practice of agroforestry systems in the dumping areas will cover the cultivation of timber trees and other woody species combined with either perennial crops, annual crops, cash crops or animal husbandry, depending on the characteristics of post-mined land.

The implementation of the Regional Regulation of Muara Enim Regency on the post-mined land by PT. Bukit Asam Coal Mining Company follows an Indonesian Government Regulation on Rehabilitation and Reclamation of Forest Land [8]. According to the regulation, two important objects subject to rehabilitation and reclamation are forest and land areas. Rehabilitation includes reforestation activities, such as replanting and maintainance of forest species, at the critical and non-productive land, while reclamation focuses on improving degraded land using forest species in order to obtain its function for conservation and productivity purposes. Post-mined land as found in the Bukit Asam areal is an example of degraded land needs to reclaim by following suitable approaches described in the government regulation. Reclamation coverages conducted in Bukit Asam area may be grouped into improved soil, water and air characteristics in the post-mined land.

This paper aims to promote several models of agroforestry in the post-mined land in South Sumatera as a new strategy in reclaiming degraded soil properties for both enviroment and economic purposes.

\section{METHODS}

\section{A. Study Location}

The study was conducted in PT. Bukit Asam Coal Mining areas located in South Sumatera Province of Indonesia (Fig. 1). The area of Bukit Asam is about $220 \mathrm{~km}$ in the south west of the province capital of Palembang. Coal mining activities in Bukit Asam began in early 1970's during the peak of oil price, and eyes of the world were opened and saw coal was a cheap alternative energy resources with large deposits. Geographical position of the location lies between $3^{0} 40^{\prime}-3^{0} 45^{\prime} \mathrm{S}$ and $103^{\circ} 40^{\prime}-103^{\circ} 48^{\prime} \mathrm{E}$, covering a total area of 7,700 ha located in Air Laya and Banko Barat sites. However, only 5,000 ha of the Bukit Asam area will be proposed for agricultural-based practices when the area is closed to mining operation, while the rest will be alocated for settlement and other non-agricultural activities.

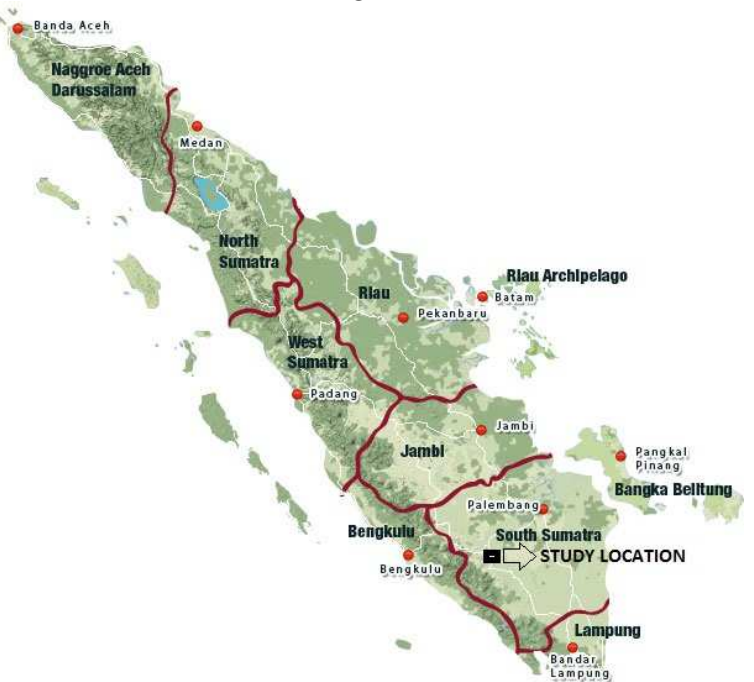

Fig. 1 Location of study area in South Sumatera Province, Indonesia [9]

The study began with the secondary data analysis on reports related to post-mined land planning and management at the study area. The desk study focused on the Bukit Asam area proposed for reclamation as described in the Regional Regulation of Muara Enim Regency. Bukit Asam coal mining areas of about 5,000 ha were then observed in July 2011 to characterize the landscape and soil properties in the area, while the progress of post-mined land reclamation was evaluated in November 2014. The study area consisted of Air Laya Site (3,000 ha) and Banko Barat Site (2,000 ha) as shown in Fig. 2, some of which has been revegetated with fast-growing trees mixed with naturally-grown pioneer shrubs. The locations of pits, dumps and active mine areas in both sites were then overlaid with the landuse maps of post-mining plans issued by the company.

The study area was divided into three blocks for conservation, collection and utilization purposes, respectively, as described in the Indonesian Government Regulation. The conservation block was a part of proposed reclamation sites that subjects to severe land degradation such as those at the steep land or located in the river banks. Sites proposed for living, growing and conservation of endangered plant and animal species was grouped into the collection blok, while commercial plant species were located at the utilization block. 


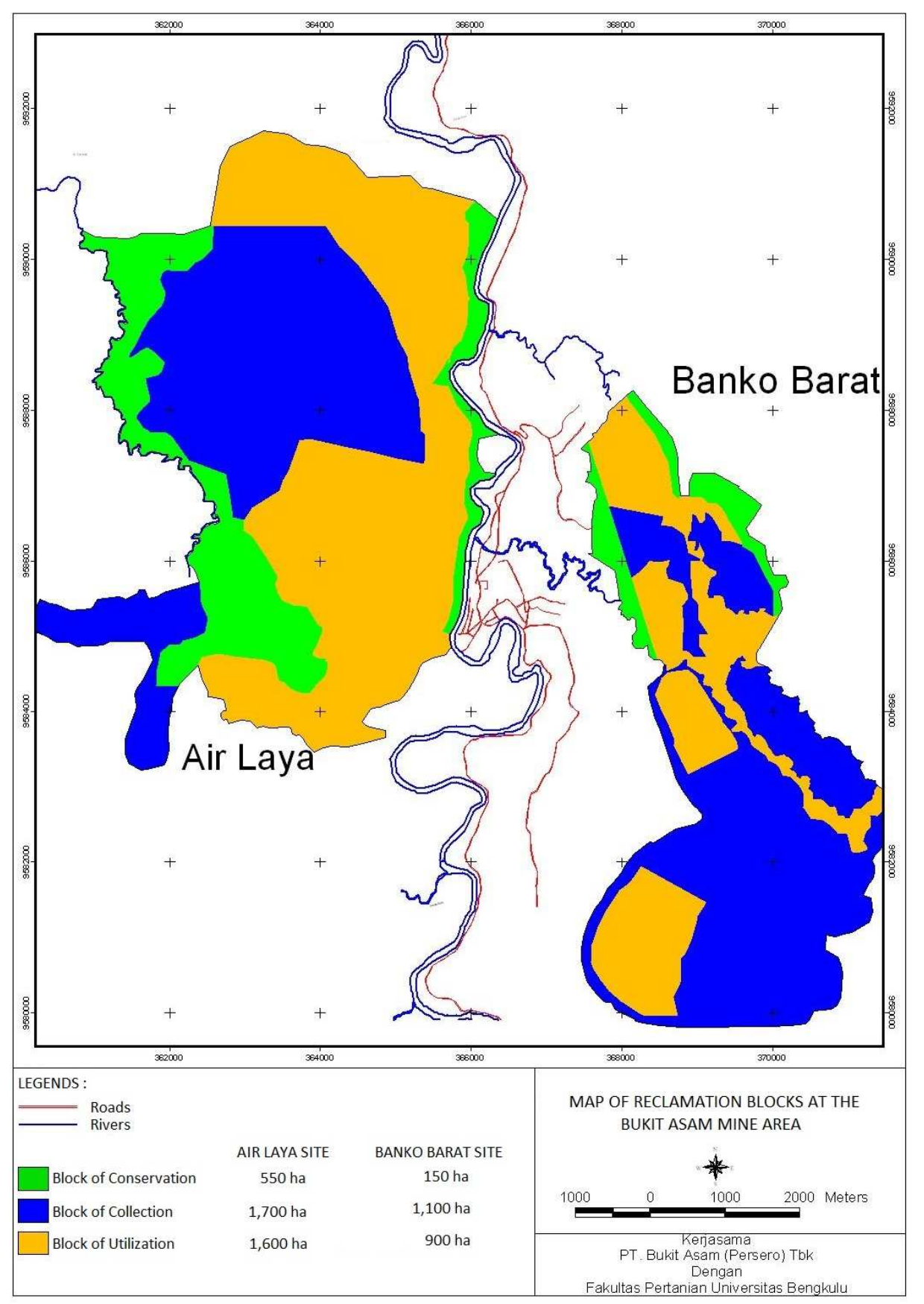

Fig. 2 A map of Reclamation Blocks at Air Laya and Banko Barat Sites

\section{B. Characterization of Study Sites}

Soil and water samples were collected from each block and analyzed at the laboratorium, to evaluate soil physical, chemical and biological properties, and land characteristics were measured to determine the land capability and suitability for various models of agroforestry development. Land capability was defined as the ability of land to be cultivated with agricultural crops or should be leaved as conserved areas, while land suitability for such a crop was classified according to the crop's growth requirements. Land and soil limiting factors for agroforestry included soil texture, soil nutrient retention and availability to the plant, soil depth, soil drainage, erosion hazards and slopes for determination of both land capability and suitability [10].
History of native plants in the study area was recorded based on the valid information from the local community living around the Bukit Asam company area in order to rebuild the structure of perennial tree-cash crops community in agroforestry models. Nearest habitats of Muara Enim native plants were inventirized and mapped for the future sources of seedling collection. The availability of infrastructure in the Bukit Asam area to support agroforestry was also recorded including nursery, greenhouse and tissue culture laboratory. The future transfer for land and tree rights from the coal company to local people was also be evaluated because the success of plant growth in the postmined land would depend on the envolvement of local community [11]. 


\section{Models Development}

The development of agroforestry models for industrialized regions including Muara Enim Regency can be furthured by recognizing the history and present function of agroforestry in the region [12]. In Muara Enim Regency, fruit trees were traditionally grown on agricultural land undershown with main cash crops such as upland rice, corn and cassava. Dominant fruit trees usually grown in the region were duku (Lansium domesticum), durian (Durio zibethinus), cempedak (Artocarpus integer), manggosteen (Garcinia mangostana), and litchi (Dimocarpus longan). The cash crop production was usually conducted for over three years, the farmer then moved to other new areas lieaving the fruit trees growing monoculturally or mixed with other types of natural woody trees. Recently, fruit trees were grown as the main commodities, while cash crops were undergrown as secondary commodities prior to fruit trees production.

Characteristics of land and soil properties at each block were used to predict suitable future models of agroforestry for food producion in the post-mined land of Bukit Asam. Each proposed model considered several limiting and supporting factors such as the position of sites, either in the conservation, collection or utilization block, soil limiting factors, and social responses to agroforestry development. The post-mined land area required by each model was also predicted from the maps.

\section{RESULTS AND DISCUSSION}

\section{A. Post-mined Land Capability and Suitability}

Prior to the agroforestry establishment, all reclamation sites were subjected to the revegetation with fast-growing trees and other rejuvenation treatments in order to restore favour soil and microclimate conditions. Several parameters of land capability at study sites are presented in Table 1. Post-mined land at Air Laya site has been planted with pioneer trees since 2005 therefore some improvements on soil and water properties were recognized during the study period. Soil $\mathrm{pH}$, for example, was about similar to that at the undisturbed land covered with secondary forest. However, soil organic carbon was lower and exchangable aluminium was higher at the dumping sites, suggesting that imrovement on soil quality by ten years practices of revegetation only occured in several variables. Similar conditions also existed in Banko Barat site, but the levels of improvements on soil and water quality were significantly lower at Banko Barat compared to Air Laya.

Results of field observation at the study area showed that about 1,730 ha of the reclamation land was suitable for agroforestry while the rest was suitable for infrastructure, camping ground, water pond, industrial forest plants and grassland. Analysis on land capability parameters at the reclamation sites proposed for agroforestry resulted in three agroforestry models, proposed as (i) agrisilviculture model (1,190 ha), (ii) silvihorticulture model (203 ha), and (iii) local-species collection model for agrihortisilviculture (337 ha). The models were developed by considering soil limiting factors such as soil depth, nutrient sources and availability of the soil and soil reaction.
TABLE I

LAND CAPABILITY FOR AGROFORESTRY AT AIR LAYA AND BANDKO BARAT SITES

\begin{tabular}{|c|c|c|}
\hline \multirow{2}{*}{ Capability } & \multicolumn{2}{|c|}{ Study Sites } \\
\hline & Air Laya & Banko Barat \\
\hline Revegetation & Pioneer tree plants & Pioneer tree plants \\
\hline $\begin{array}{l}\text { Years of } \\
\text { planting }\end{array}$ & 2005 & $\begin{array}{l}2005 \\
2015\end{array}$ \\
\hline $\begin{array}{l}\text { Soil biophysics } \\
\text { at dumping sites }\end{array}$ & $\begin{array}{l}\mathrm{pH}: 4.5 ; \\
\mathrm{C}-\text { org: } 2.03 \% \text {; } \\
\mathrm{Al}: 4.20 \mathrm{me} / 100 \mathrm{~g}\end{array}$ & $\begin{array}{l}\text { pH: } 4.6 ; \\
\text { C-org: } 1.59 \% \\
\mathrm{Al}: 6.74 \mathrm{me} / 100 \mathrm{~g}\end{array}$ \\
\hline $\begin{array}{l}\text { Undisturbed } \\
\text { sites }\end{array}$ & $\begin{array}{l}\mathrm{pH}: 4,4 \\
\text { C-org: } 3.4 \%\end{array}$ & $\begin{array}{l}\mathrm{pH}: 4.5 \\
\text { C-org: } 6.8 \%\end{array}$ \\
\hline Water quality & $\begin{array}{l}\mathrm{NO}_{3}: 0.05 \mathrm{mg} / \mathrm{L} \\
\mathrm{PO}_{4}: 0,71 \mathrm{mg} / \mathrm{L} \\
\mathrm{SO}_{4}: 215 \mathrm{mg} / \mathrm{L}\end{array}$ & $\begin{array}{l}\mathrm{NO}_{3}: 0.11 \mathrm{mg} / \mathrm{L} \\
\mathrm{PO}_{4}: 0,95 \mathrm{mg} / \mathrm{L} \\
\mathrm{SO}_{4}: 275 \mathrm{mg} / \mathrm{L}\end{array}$ \\
\hline $\begin{array}{l}\text { Soil limiting } \\
\text { factors }\end{array}$ & $\begin{array}{l}\text { Depth, organic } \\
\text { carbon, exch-Al }\end{array}$ & $\begin{array}{l}\text { Depth, organic } \\
\text { carbon, exch-Al }\end{array}$ \\
\hline Mine land types & $\begin{array}{l}\text { Dumping areas, } \\
\text { backfilling }\end{array}$ & Dumping areas \\
\hline Land suitability & $\begin{array}{l}\text { Agrisilviculture; } \\
\text { Sivihorticulture; } \\
\text { Local-species } \\
\text { collection for } \\
\text { agrihortisilviculture }\end{array}$ & $\begin{array}{l}\text { Agrisilviculture; } \\
\text { Local-species } \\
\text { collection for } \\
\text { agrihortisilviculture }\end{array}$ \\
\hline
\end{tabular}

Two models of agrisilviculture and local-species collection for agrisilvihorticulture were located at both Air Laya and Banko Barat sites, while the silvihorticulture model was only located at Air Laya site (Fig. 3). Agrisilviculture and silvihorticulture models were parts of Utilization Block and local-species collection of agrisilvihorticulture model was a part of Collection Block. All three models were developed to obtain the land cover by tree plants as well as to produce food for the citizen living at the surrounding villages. There was no agroforestry model was suggested in the Conservation Block at both sites because the conserved areas would be grown with conservation plants such as bamboo and other tree species having deep and strong rooting systems to strengthen the soil at the steepland and at the river banks.

\section{B. Model 1: Agrisilviculture}

Combining trees and cash crops in the agrisilviculture model improved the efficiency of utilisation of resources (light, water, nutrients) and thus lead to an overall higher biomass production [13]. Simultaneously, soil erosion and nitrate leaching were reduced and landscape biodiversity was increased. In this study, agrisilviculture model was designed for a mixed farming system between woody tree plants and cash crops. Cash crops were usually grown in the first three years following tree plants planting, before the tree canopy covered soil surface. This model followed the traditional planting systems of tree plants and cash crops practized by the people of Muara Enim Regency in the last three decades. Tradtionally, when cash crops such as upland rice and corn were harvested for two or three consecutive years, the farmers moved to other areas leaving the land grown with woody tree plants such as sungkai and local merbau (Intsia palembanica Miq.). Therefore, the agrisilviculture model was developed in order to rebuild the traditional agricultural practices in the region before the presence of coal mining activities in Muara Enim Regency. 


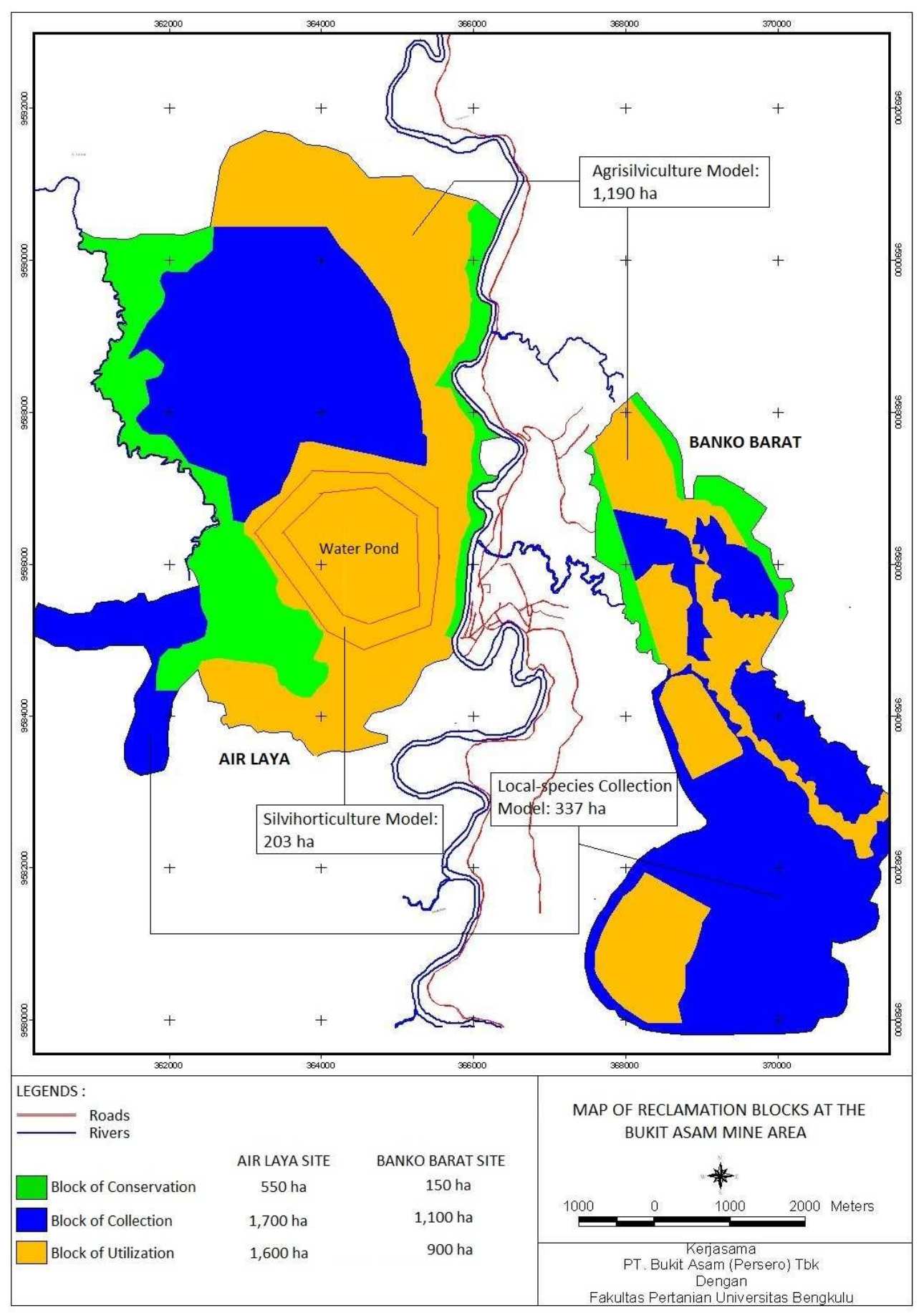

Fig. 3 Locations of the proposed Agroforestry models at Air Laya and Banko Barat Sites

The model occupied the area of 1,190 ha, located in the north parts of dumping areas at Air Laya and Banko Barat sites. The area has been revegetated since 2005 with various reclamation tress in order to improve soil physical, chemical and biological properties. When the reclamation tree plants were about ten years or more after palnting, the commercial woody trees might substituted the reclamation trees. At the same time, cash crops might be undershown betwee commercial woody perennial trees that were planted to replace reclamation trees. The proposed component for agrisilviculture model were therefore cultivation on the alley cropping system of trees and food crops.

The model of agrisilviculture had some advantages from the mixture of woody perennial trees and herbaceous cash crops. When applied in conjunction with conservation tillage and mulching, the practice might retain soil organic carbon compared to that with coventional tillage [14]. Minimized wind and water erosion might also be achieved when the model was combined with shelterbelt tree planting to protect agricultural land [15]. Establishment of perennial multipurpose tree species resulted in sequester $\mathrm{CO}_{2}$, while managing water level, cultivars, fertilization and tillage of paddy might reclaim degraded land. Agrisilviculture had the ability to provide short-term economic benefits from cash crops while the farmer waits for traditional longer-term forestry products. 


\section{Model 2: Silvihorticulture}

The silvihorticulture model (203 ha) was located at the southern part of Air laya site, the model was the plantation of fruit trees in the bench of water pond as illustrated in Fig. 4. The mining company would not be able to cover all pit areas formed during the mining operations, therefore the area would be left open and filled with water. However, the bench of the lake migh be covered with spreadeing materials transported together with coals. The width of bench was about 250 meter from the edge of lake and be used as the planting area of food trees. Soil quality, however, needed to be improved since the horticultural plants especially fruit trees would not be able grow well under unfavourable conditions of the soil.

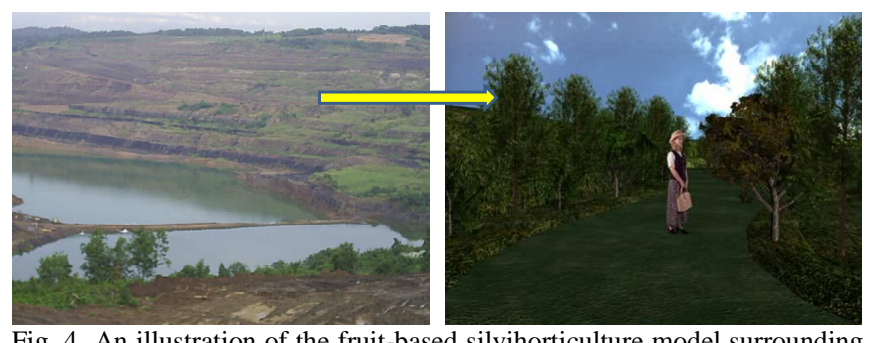

Fig. 4 An illustration of the fruit-based silvihorticulture model surrounding the lake for future post-mined landuse in the study area

Prior to the establishment of silvihorticulture model, the planting media should fullfil the plant-growing requirement, physically, chemically and biologically. Post-mined soils, especially when constructed from unweathered rock spoils, usually contain very little organic carbon therefore unadequate available nitrogen and phosforus for plant growth [16]. Soil organic carbon should be greater than $2.0 \%$, and could be achieved more rapidly at the uppermost soil profile $(0-15 \mathrm{~cm})$ [17], while some important soil untrients such as nitrogen, phosporous and potassium should be at the category of medium until high. The proper conditions at the uppermost soil surface might be achieved by constructing terraces, planting reclamation plants and speeding up the organic mater decomposition processes using earthworms and other suitable material-decomposing microbes.

Establishment of silvihorticulture model might be conducted by dividing the bench area into three parts. In the upper part, the sub-area might be planted with woody fruit trees supported with infrastructure such as the guard house, storage house, restaurant, car parks and public fasilities. Terraces in the midle of slope might be function fully for fruit trees. This sub-area was the largest in the silvihorticulture model, therefore the plantation could be arranged according to the fruit diversity. For example, visitors could pick up their own fruits while walking around the area. The lowest part of the area boardered to the lake, therefore the tourism atmosphere should be dominant and the presence of fruit trees would be the supporting object of tourism.

\section{Model 3: Local-species Collection for Agrihortisilviculture}

The proposed local-species collection model for Agrihortisilviculture consisted of selected plant species from tropical fruit and woody perennial plant families of Dipterocarpaceae and non-Dipterocarpaceae as well as from endangered species. Appearance of the tree plant composition in the collection model was illustrated in Fig. 5. The local-species collection model for agrihortisilviculture occupied an area of 337 ha locating at Collection Block of reclamation in both Air Laya and Banko Barat sites. The main components for local-species collection model of agrihortisilviculture were the cultivation of local forest and food crop species.

The general function of the collection model would be for conservation of local species of food plants rather than for commercial food production. Detail functions of the model development were as follows. First, the area of collection model functioned as an ex-situ conservation for endangered local species of Dipterocarpaceae and an in-situ conservation for local species commonly found in the primer forest in Muara Enim Regency. Second, the model functioned as a source of mother plants for breeding programs in the future. The survival of endangered and local species would be responsibility of the model development. Third, the collection model functioned as a field laboratory for education, research and science development purposes espcially about Dipterocarpaceae, tropical fruits and endangered species. Fourth, the area of collection model would be functioned like a "showroom" for benefecial plants that could be developed in the future by farmers and forest managers. Fith, Muara Enim Regency is an industrial area having a lack of tourism objects, therefore this model offered several outdor activities to get fresh air as well as to learn about plants from the collection of local species.

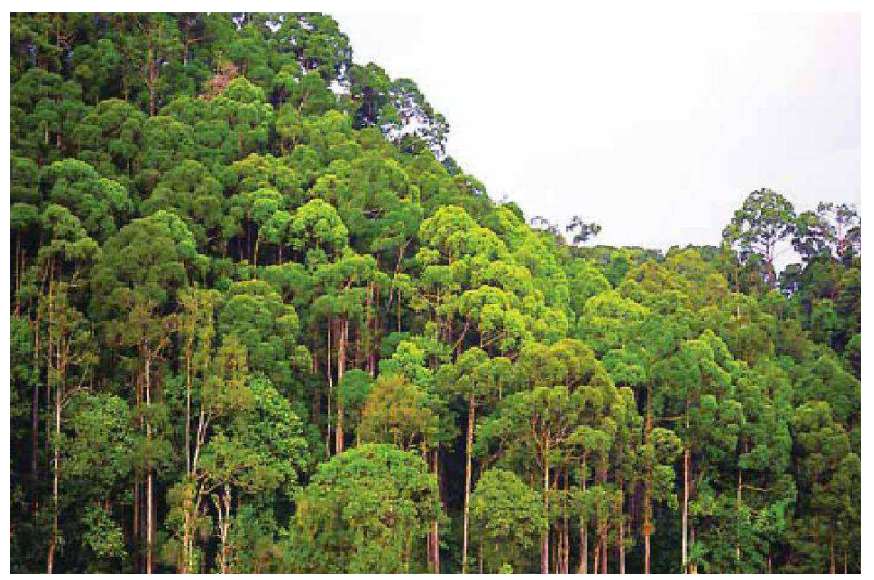

Fig. 5 An illustration of the local-species collection of agrihortisilviculture model

Plant species grown in the collection model mainly consisted of fruit and timber trees resulting in wide gaps between the trees, therefore the model required a large area to accomodate various species. The area of 337 ha had different land characteristics that were suitable for collected plants, therefore each individual species could grow well in the new habitat. Fruit and timber trees could be planted in such a pattern according to the sites of their taxonomy and origins, therefore the visitors could have better information about the species. 
To support food production, collected fruit and timber trees would be undershown with carbohydrate-resulting tuber species. Tuber species were chosen as food crops in the collection model because of their suitability to grow under the trees as usually found in the natural forest. Compared to commonly consumed food crops such as rice and corn, production of tuber crops was five to seven times higher in the tropical region including the study area [18]. Integration between traditional and modern knowledge systems would also be useful to develop tuber crops production [19].

In order to run its function as an information center for tree and tube species collection, the area should be equiped with information facilities, spreaded out in the field and in such a place used as an information center. The information included the site plant map showing the location of each species, description of plant taxonomy, origins of species, and the beneficial of the plant traditionally and scientifically. Other facilities included pedestrian and jogging tracks, car parks and public utilities that could be used for tourism purposes.

\section{CONCLUSIONS}

Three suitable models of agroforestry proposed for food production in the post-mined land of study sites were agrisiviculture, silvihorticulture and local-species collection of agrihortisilviculture. The three models occupied areas of 1,730 ha located at two mining sites in Muara Enim Regency, South Sumatera, Indonesia. Agrisilviculture model was a mixed farming system between woody perennial trees and cash crops, silvihorticulture model was a fruit trees system as a supporting objeck of tourism, and collection model was an area grown with various local and endangered food-

\section{ACKNOWLEDGMENT}

The author would like to thank PT. Bukit Asam (Persero) Tbk for funding and other facilites of the study. Thanks also go to Sukisno for land mapping, as well as Mansyur and Suroto for soil analysis.

\section{REFERENCES}

[1] PT. Bukit Asam, Mine Enclosure of Air Laya and Muara Tiga Besar Sites, Cooperate Presentation. Palembang (South Sumatera): 14 October 2014.
[2] B. Hermawan, "Characterization of post-mined soils as pre-planning for Great Forest Park", in Proc. Nat. Seminar on Indo. Soc of Conservation Community, 2010.

[3] B. Hermawan and K. S. Hindarto, "Improved post-mined soil quality following twelve-years growth of reclamation vegetation", in Proc. Nat. Seminar on BKS-Barat, 2011.

[4] A.Singh. (2015) Science Log website. [Online]. Available: http://www.sciencelog.net/2015/05/agroforestry-systems-practicestechnologies.html

[5] M. E. Isaac, E. O. Adjei, R. N. Issaka, and V. R. Timmer, "A strategy for tree-perennial crop productivity: nursery phase nutrient additions in cocoa-shade agroforestry systems", Agroforest Syst., vol. 81, pp. 147-155, 2010.

[6] E. Somarriba and J. Beer, "Productivity of Theobroma cacao agroforestry systems with timber or legume service shade trees", Agroforest Syst., vol. 81, pp. 109-121, 2010.

[7] Regional Regulation of Muara Enim Regency on The Use of PostMined Land for a Great Forest Park, Muara Enim, 2004.

[8] Indonesian Government Regulation on Rehabilitaion and Reclamation of Forest Land, Jakarta, 2008.

[9] (2015) The Map of South Sumatera, Indonesia. [Online]. Available: https://www.google.com/search?q=peta+sumatera+selatan+english\&i e $=$ utf- $8 \&$ oe $=$ utf -8

[10] B. Hermawan, Soil and Water Conservation, Bengkulu University Publisher. Bengkulu: 2010.

[11] T. Martial and Mhd. Assad, "The land and tree tenure-based Dalihan Notalu Customs for tree management in South Tapanuli, North Sumatera", International Journal Advance Sience Engineering Information Technology, vol. 6 no. 2, pp. 180-185, 2016.

[12] F. Herzog, "Streuobst: a traditional agroforestry system as a model for agroforestry development in temperate Europe", Agroforest Syst., vol. 42, pp. 61-68, 1998.

[13] D. Freese, C. Böhm, and A. Quinkenstein, "The Contribution of Agroforestry Systems to Land Reclamation", Górnictwo Geoinżynieria, vol. 35 no. 3, 2011.

[14] R. Bhattacharrya, M.D. Tuti, S. Kundu, J.K. Bisht, and J.C. Bhatt, "Conservation tillage impacts on soil aggregation and carbon pools in a sandy clay loam soil of the Indian Himalayas", Soil Sci. Soc. Am. J., vol. 76 no. 2, pp. 617-627, 2012.

[15] B.Y. Amichev, M.J. Bentham, D. Cerkowniak, J. Kort, and S Kulshreshtha, "Maping and quantification of planted tree and shrub shelterbelts in Saskatchewan, Canada", Agroforest Syst., vol. 89 no. 1, pp. 49-65, 2015.

[16] C.E. Zipper, J.A. Burger, C.D. Barton, and J.G. Skousen, "Rebuilding soils on mined land for native forests in Appalachia", Soil Sci. Soc. Am. J., vol. 77 no. 2, pp. 337-649, 2012.

[17] L.R. Cook, J.L. Stape, and D. Binkley, "Soil carbon dunamics following reporestration of tropical pastures, Soil Sci. Soc. Am. J., vol. 78 no. 1, pp. 290-296, 2014.

[18] H. Malik, Releasing Imported Food Traps, LP3ES Publisher. Jakarta: 2014.

[19] D. Wendiro, W. Wamae, A. Kingiri, M. Dhabangi, and P.A. Wacoo, "Innovation dynamics in cassava production systems in Uganda", Journal of Agricultural Biotechnology and Sustaibale Development, vol. 6 no. 5, pp 50-59, 2014. 